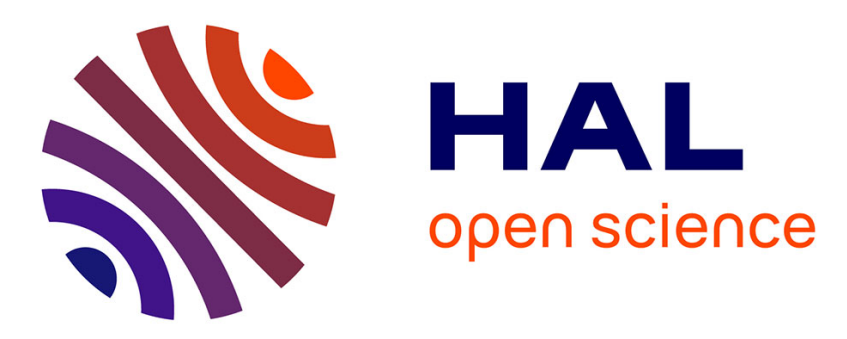

\title{
Integrated modeling of water and heat fluxes in the Seine hydrosystem, France
}

Deniz Kilic, Agnès Rivière, Nicolas Flipo, Agnès Ducharne, Philippe Peylin, Patrick Goblet

\section{- To cite this version:}

Deniz Kilic, Agnès Rivière, Nicolas Flipo, Agnès Ducharne, Philippe Peylin, et al.. Integrated modeling of water and heat fluxes in the Seine hydrosystem, France. EGU General Assembly 2021, Apr 2021, online, France. 10.5194/egusphere-egu21-4351 . hal-03199255

\section{HAL Id: hal-03199255 \\ https://hal.sorbonne-universite.fr/hal-03199255}

Submitted on 15 Apr 2021

HAL is a multi-disciplinary open access archive for the deposit and dissemination of scientific research documents, whether they are published or not. The documents may come from teaching and research institutions in France or abroad, or from public or private research centers.
L'archive ouverte pluridisciplinaire HAL, est destinée au dépôt et à la diffusion de documents scientifiques de niveau recherche, publiés ou non, émanant des établissements d'enseignement et de recherche français ou étrangers, des laboratoires publics ou privés. 
EGU21-4351, updated on 15 Apr 2021

https://doi.org/10.5194/egusphere-egu21-4351

EGU General Assembly 2021

(c) Author(s) 2021. This work is distributed under

the Creative Commons Attribution 4.0 License.

\title{
Integrated modeling of water and heat fluxes in the Seine hydrosystem, France
}

\author{
Deniz Kilic ${ }^{1}$, Agnès Rivière ${ }^{1}$, Nicolas Flipo ${ }^{1}$, Agnès Ducharne ${ }^{2}$, Philippe Peylin ${ }^{3}$, and Patrick Goblet ${ }^{1}$ \\ ${ }^{1}$ Geosciences Department, MINES ParisTech, PSL University, Fontainebleau, France (deniz.kilic@mines-paristech.fr) \\ ${ }^{2}$ METIS (Milieux Environnementaux, Transferts et Interactions dans les Hydrosystèmes et les Sols), Institut Pierre Simon \\ Laplace (IPSL), Sorbonne Université, CNRS, EPHE, Paris, France \\ ${ }^{3}$ Laboratoire des Sciences du Climat et de l'Environnement, LSCE/IPSL, CEA-CNRS-UVSQ, Université Paris-Saclay, F-91191, \\ Gif-sur-Yvette, France
}

Given the current climate and anthropogenic evolution, water management becomes one of the greatest challenges of the 21st century. Number of studies have analyzed observed hydrologic trends and their connections with the changing climate. Impacts include changes in runoff, river discharge and groundwater recharge. Water quality is also impacted, through its many facets including the water temperature. Despite the important progress made in climate modelling, the impact of the predicted global warming on hydrological processes remains uncertain; particularly, in large hydrosystems. The Seine River basin has a surface of $78,650 \mathrm{~km}^{2}$, it includes the Seine River and its 50 tributaries, it is populated by $30 \%$ of France inhabitants. The Seine River basin crosses 14 departments and 4 regions, including the Paris metropolitan area. Climate change poses a vulnerability due to its potential political, social, and economic consequences in the Seine basin. The agricultural activities and number industries depend on water resources or are located on the river sides. Our ability to adapt water resource management strategies to the climate change depends on our ability to understand and estimate the actual evolution of water resource.

The terrestrial water budget is now considered as a single continuum. This integrated conceptualisation needs to simulate the spatial and temporal dynamics of water exchanges between the surface and groundwater. Here we propose to improve the representation of the surface water budget with the goal to decrease the uncertainty of the whole water budget of the Seine hydrosystem. We used the process-based physical land surface model ORCHIDEE (tag 2.2) to estimate surface water budget and heat balance for the period 1980-2018. This application takes advantage of high resolution land-use and albedo maps from ESA-CCI database, and various soil map databases. The model was satisfactorily able to reproduce the discharges of each subcatchment, the actual evapotranspiration fluxes and LAI. With these results, we are able to estimate the the partitioning of the surface water balance of each catchment of the Seine basin. These results have wide ranging implications such as the estimation of energy balance in the basin, the estimation of spatialisation of the aquifer recharge, and the feedback between aquifers and the surface. 